\title{
Lectotypification of two names in Limoniastrum (Plumbaginaceae)
}

\author{
P. Pablo Ferrer-Gallego, ${ }^{1 *}$ Duilio Iamonico, ${ }^{2 *}$ Mauro Iberite, ${ }^{3}$ Emilio Laguna ${ }^{1} \&$ Manuel B. Crespo ${ }^{4}$ \\ 1 Servicio de Espacios Naturales y Biodiversidad, Centro para la Investigación y Experimentación Forestal (CIEF), Generalitat \\ Valenciana, Avda. Comarques del País Valencià 114, 46930 Quart de Poblet, Valencia, Spain \\ 2 Laboratory of Phytogeography and Applied Geobotany, Section Environment and Landscape, Department PDTA, University of \\ Rome Sapienza, 00196 Rome, Italy \\ 3 Department of Environmental Biology, University of Rome Sapienza, 00185 Rome, Italy \\ 4 CIBIO (Instituto de la Biodiversidad) \& Departamento de Ciencias Ambientales y Recursos Naturales, Universidad de Alicante, \\ Apartado 99, 03080 Alicante, Spain \\ Author for correspondence: Manuel B. Crespo, crespo@ua.es \\ * contributed equally to this work \\ DOI http://dx.doi.org/10.12705/636.4
}

Abstract The halophytic shrub genus Limoniastrum has recently been recircumscribed to include only two Mediterranean-
Saharan species, Limoniastrum monopetalum (L.) Boiss. (EStatice monopetala L.) and L. guyonianum Boiss. Protologues of
both species are briefly discussed and lectotypes are designated using material at BM (Herb. Clifford) and G (Herb. Boissier).

Keywords lectotypification; Limoniastrum guyonianum; Linnaean name; Plumbaginoideae; Statice monopetala

\section{口INTRODUCTION}

The genus Limoniastrum Heist. ex Fabr. (Plumbaginaceae) currently comprises two species of halophytic shrubs, L. monopetalum (L.) Boiss. ( $\equiv$ Statice monopetala L.) and L. guyonianum Boiss. (Crespo \& Lledó, 2000; Lledó \& al., 2000), which are found mostly in coastal and saline dry areas of the Mediterranean and northern Saharan Africa (Ozenda, 1983; Dijkema \& al., 1984; Barone \& al., 1995). The molecular study by Lledó \& al. (2000) showed that Limoniastrum s.l. was not monophyletic as traditionally circumscribed, and it was divided into three genera, Ceratolimon M.B.Crespo \& Lledó, Limoniastrum s.str., and Saharanthus M.B.Crespo \& Lledó, each well characterized from morphological and biogeographical points of view (Crespo \& Lledó, 2000; Fabregat \& al., 2003). This multigeneric classification had previously been accepted by Linczevski (1968), who had, however, applied two names that are not admissible (Crespo \& Lledó, 2000): Bubania Girard, nom. nov. pro Limoniastrum L., nom. superfl. et illeg. (Art. $52.1 \& 52.2$ in McNeill \& al., 2012) (currently named Ceratolimon) and "Caballeroa" Font Quer, nom. inval., provisionally proposed but not accepted by the author as a replacement name for Lerrouxia Caball. 1935, non Lerouxia Mérat 1812 (see Crespo \& Zijlstra, 2012; Applequist, 2013) (currently named Saharanthus).

Species of Limoniastrum s.str. are ecologically and economically significant (Debouba \& al., 2013). Limoniastrum monopetalum was described from Sicily (Italy) by Linnaeus (1753: 276) as Statice monopetala. It is a shrub of whitishgrey aspect, with leaves narrowly spathulate, and stems and branches densely beset with white calcareous depositions. This species has been the subject of many studies regarding its ecology, distribution, genetics and taxonomy (El-Shourbagy \& al., 1984; Rubio \& al., 1984; Crespo \& Lledó, 2000; Lledó \& al., 2000; El-Morsi, 2010; Zahran \& El-Amier, 2013). Limoniastrum guyonianum was described by Boissier (1848: 689) from eastern Algeria, during the French scientific expeditions carried out in northern Africa within the 19th century, though it extends through Egypt (Greuter \& al., 1989). It resembles L. monopetalum but is readily recognized by its narrower sub-cylindrical leaves, divaricated many-branched inflorescence, and smaller flowers (Quézel \& Santa, 1963; Qaiser \& Siddiqi, 1984; Boulos, 2000). It has been used in local communities as forage for camels (Laudadio \& al., 2009), and recently its medicinal potential has been reassessed (Trabelsi \& al., 2012; Debouba \& al., 2013; Krifa \& al., 2013).

From the standpoint of nomenclature, both species names appear to be not yet typified and they are investigated here as part of the researches on the genus Limoniastrum and relatives in both the project "Flora Valentina" (by P.P. Ferrer-Gallego, E. Laguna, and M.B. Crespo-see, e.g., Crespo \& Lledó, 2000; Lledó \& al., 2000; Crespo \& Zijlstra, 2012) and the initiative "Italian Loci Classici Census" (by D. Iamonico and M. Iberite—see, e.g., Iamonico, 2012; Iamonico \& Peruzzi, 2014; Iberite \& al., 2013).

\section{TYPIFICATIONS}

Limoniastrum Heist. ex Fabr., Enum.: 25. 1759 三 Bubania Girard in Mém. Sect. Sci. Acad. Sci. Montpellier 1: 182. 1848, nom. superfl. et illeg. $\equiv$ Limoniodes Kuntze, Revis.

Received: 22 Mar 2014 | returned for first revision: 18 Jun 2014 | last revision received: 2 Jul 2014 | accepted: 6 Oct 2014 | published online ahead of inclusion in print and online issues: 3 Dec 2014 || (C) International Association for Plant Taxonomy (IAPT) 2014 
Gen. Pl. 2: 394. 1891, nom. superfl. et illeg. - Type: Limoniastrum articulatum Moench, nom. superfl. et illeg. (三 Statice monopetala L.; Limoniastrum monopetalum (L.) Boiss.).

\section{Statice monopetala}

Linnaeus's protologue (1753: 276) consists of "STATICE caule fruticoso folioso, floribus solitariis, foliis lanceolatis vaginantibus", followed by two synonyms, the first one ("Statice foliis caulinis lanceolato-linearibus") cited from Linnaeus (1738: 116) and Royen (1740: 192), the second synonym ("Limonium lignosum") from Boccone (1674: 34, 35); the provenance ("Habitat in Sicilia") is also provided. Boccone (1.c.) presented two illustrations (tt. 16 and 17) that can be considered original material for the name Statice monopetala.

One specimen useful for the purposes of typification is preserved at BM (Herb. Clifford: 116, Statice 3, barcode 000558477 [digital image!]). This sheet bears a plant with leaves and flowers, and the annotation by Linnaeus "Limonium siculum lignosum, gallas ferens et non ferens / Statice monopetala", partially linked to the Boccone's synonym cited by Linnaeus (1753). This material is part of the original material and elegible as lectotype.

In the Linnaean Herbarium at LINN there is a sheet (No. 395.18, image available at: http://linnean-online.org/3697/), containing two specimens in very good condition. However, this sheet lacks the relevant Species Plantarum number ("11" in the case of $S$. monopetala) and is to be considered a post-1753 addition to the collection and not original material for the name (the Linnaean script is "S. monopetala") (see Turland \& Jarvis, 1997; Turland, 2006; Jarvis, 2007). Actually, this plant came from C. Alströmer (there is also Alströmer's annotation "33.a.").

Furthermore, a herbarium sheet was found in Herb. Smith at LINN (No. 552.6) which contains three specimens of Statice monopetala (No. 552.6.1-image available at: http://linneanonline.org/33761/; No. 552.6.2 -image available at: http:// linnean-online.org/33762/; No. 552.6.3 -image available at: http://linnean-online.org/33763/). However, this material is part of the Smith's collection and thus is not original material, it being a post-1753 acquisition (see Jarvis, 2007: 228-229).

Finally, one sheet is preserved at S-LINN (IDC 132.5, image available at: http://linnaeus.nrm.se/botany/fbo/s/bilder/ stati/statmon1.jpg), containing two specimens with leaves and flowers in very good condition, and bearing the annotation "11 monopetala". According to C.E. Jarvis (pers. comm.), several difficulties exist to accept this sheet as original material. Although it is possible (but not certain) that the "11" (that matches the relevant Species Plantarum number) was written by Linnaeus, "monopetala" was indeed written by his son. In addition, Linnaeus added a symbol at the base of the specimen that is associated with specimens collected by Hasselquist in the Middle East. There is also a question about the date of acquisition. Most of Hasselquist's specimens reached Linnaeus after publication of Species Plantarum, and probably the sheet 132.5 is one of those post-1753 additions (C.E. Jarvis, pers. comm.). For this reason Jarvis (2007) has not included the S-LINN sheet as original material, and consequently we prefer to leave it apart.

We have been unable to trace any further original material in any other Linnaean and Linnaean-linked herbaria.

All the elements discussed (specimen from Clifford; illustrations by Boccone) match the Linnaean diagnosis and correspond to the current concept of the species (see, e.g., Quézel \& Santa, 1963; Pignatti, 1972; Guinochet \& Vilmorin 1973; Crespo \& Lledó, 2000). Although the illustration in Boccone (1674) is fully identifiable as Linnaeus's Statice monopetala, the specimen in BM (Herb. Clifford: 116, Statice 3) is selected here, since a specimen is generally preferable to an illustration.

Limoniastrum monopetalum (L.) Boiss. in Candolle, Prodr. 12: $689.1848 \equiv$ Statice monopetala L., Sp. Pl.: 276. $1753 \equiv$ Limoniastrum articulatum Moench, Methodus: 423. 1794, nom. illeg. (Art. $52.1 \& 52.2$ ) 三 Bubania monopetala (L.) Girard in Mém. Sect. Sci. Acad. Sci. Montpellier 1: 183. $1848 \equiv$ Limoniodes monopetala (L.) Kuntze, Revis. Gen. Pl. 2: 394 . 1891 - Lectotype (designated here): Herb. Clifford: 116, Statice 3 (BM barcode 000558477 [digital image!]). — Image of lectotype available at http://www.nhm.ac.uk/ resources/research-curation/projects/clifford-herbarium/ lgimages/BM000558477.JPG

\section{Limoniastrum guyonianum}

Limoniastrum guyonianum was described by Boissier (1848: 689), who attributed the authorship of the species to Michel Ch. Durieu de Maissonneuve, and placed his new species together with L. monopetalum. Original material of the former was collected in May 1847 by Dr. Jean L.G. Guyon, in the surroundings of Biskrah (or Biscara), eastern Algeria, an area where the plant was said to be abundant (Guyon, 1852: 237; Guenée, 1870).

Several specimens have been studied including material matching Boissier's protologue and corresponding to the current concept of the species. They all were collected by Guyon at the type locality, and were later distributed to several researchers who conserved them in their personal herbaria. Two sheets, which are relevant for the purposes of typification, are at G-BOIS. Sheet G00309004 [digital image!] includes two labels ("Statice Guyoniana Boiss. / Très répandu dans le terrain rocailleux du / territoire de Biskrah. Rare dans le sable. / Recueillé par M. Guyon Chirurgien en Chef de / l'armée d'Afrique au pourtour des eaux thermales / de Biskrah, le $1^{\text {er }}$ mai 1847.", and "Limoniastrum guyonianum Durieu") and it can be considered part of the original material. Sheet G00309003 [digital image!] cannot be accepted as original material, since it represents a post-addition to Boissier's collection (the sheet bears the script "Dans les environs de / Biscara, parmi les rochers / (Algerie) / M. Guyon 1849").

Relevant material is also preserved at MPU (Frédéric de Girard's collections). The sheet MPU021562 [digital image!] includes material belonging to L. guyonianum, which was sent to Girard by Guyon in November 1848. It is currently marked 
as "isotype", though it should probably be regarded as an isosyntype.; it may not have been examined by Boissier.

Material is at M which is also marked as "isotype". The sheet M-0105918 [digital image!] includes several fragments probably from a single plant and bears two labels. One of them ("Statice Guyonii Dur. / Nota. Sur cette plante croit / une gale due à une nouvelle / espèce de phalène, qui vient / d'être nommée Oecocecis / Guyonella Guenée") is handwritten by Guyon, and lacks any indication to collection locality and date. The second label includes the scripts "HERBARIUM REGIUM MONACENSE" (typewritten) and "Limoniastrum guyonianum / Durieu / Schultes" (handwritten), plus "ALGIER. [pressed]

Fig. 1. Lectotype of Limoniastrum guyonianum Boiss. (G00309004). (Photograph by courtesy of the herbarium G; reproduced with permission).

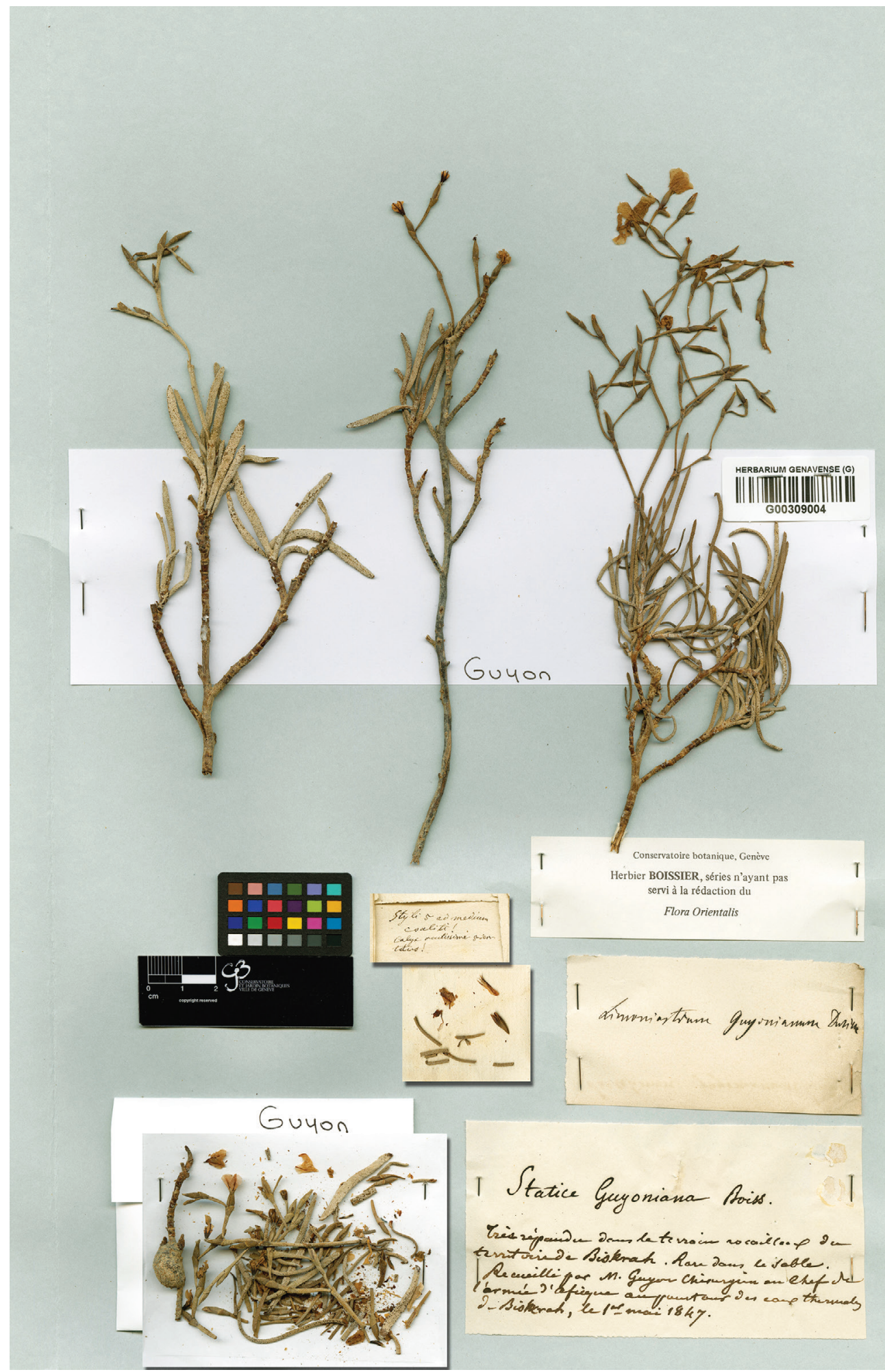


1845 " and "GUYON. [pressed]" and it was probably added to complement the former. The collection year is perhaps incorrect as the specimens used for the description of Limoniastrum guyonianum were collected in 1847 (see Guyon, 1852). It is not considered for lectotypification, since it cannot conclusively be accepted as original material.

According to all statements above, the sheet G00309004 appears to be the only extant original material for the name Limoniastrum guyonianum that was examined by Boissier. Fortunately it corresponds to the current concept of the species (see, e.g., Quézel \& Santa, 1963; Qaiser \& Siddiqi, 1984; Boulos, 2000) and it is therefore designated as lectotype.

Limoniastrum guyonianum Durieu ex Boiss. in Candolle, Prodr. 12: 689. 1848 इ Limoniodes guyoniana (Durieu ex Boiss.) Kuntze, Revis. Gen. Pl. 2: 394. 1891 - Lectotype (designated here): "Très répandu dans le terrain rocailleux du territoire de Biskrah. Rare dans le sable. Recueillé par M. Guyon Chirurgien en Chef de l'armée d'Afrique au pourtour des eaux thermales de Biskrah, le $1^{\text {er }}$ mai $1847^{\prime}$ (G barcode G00309004 [digital image!]). — For an image of the lectotype, see Fig. 1.

\section{ACKNOWLEDGEMENTS}

We kindly thank Charlie E. Jarvis (British Museum Natural History, London) for bringing crucial information and critical comments on some Linnaean materials of Statice monopetala. Gerry Moore (USDA, Greensboro) made interesting suggestions that improved the text. The curators and staff of the herbaria G, LINN, M, MPU, and S-LINN are also thanked for digital images of Limoniastrum taxa.

\section{口 LITERATURE CITED}

Applequist, W.L. 2013. Report of the Nomenclature Committee for Vascular Plants: 65. Taxon 62: 1315-1326. http://dx.doi.org/10.12705/626.49

Barone, R., Scholz, S. \& Mesa, R. 1995. Limoniastrum monopetalum (L.) Boiss. (Plumbaginaceae), adición a la flora de Fuerteventura (Islas Canarias). Bot. Macaronés. 21: 59-60.

Boccone, P. 1674. Icones \& descriptiones rariorum plantarum Siciliae, Melitae, Galliae, \& Italiae. [Oxford]: E. Theatro Sheldoniano, apud Robertum Scott.

Boissier, E. 1848. Plumbaginaceae. Pp. 617-696 in: Candolle, A.P. de (ed.), Prodromus systematis naturalis regni vegetabilis, vol. 12. Parisiis: sumptibus Victoris Masson. http://dx.doi.org/10.5962/bhl.title.286

Boulos, L. 2000. Flora of Egypt, vol. 2. Cairo: Al Hadara Publishing.

Crespo, M.B. \& Lledó, M.D. 2000. Two new North African genera related to Limoniastrum (Plumbaginaceae). Bot. J. Linn. Soc. 132: 165-174. http://dx.doi.org/10.1111/j.1095-8339.2000.tb01212.x

Crespo, M.B. \& Zijlstra, G. 2012. Request for a binding decision on whether Lerouxia Mérat (Primulaceae) and Lerrouxia Caball. (Plumbaginaceae) are sufficiently alike to be confused. Taxon 61: 1335.

Debouba, M., Zouari, S. \& Zouari, N. 2013. Evaluation of antioxidant status of two Limoniastrum species growing wild in Tunisian salty lands. Antioxidants 2: 122-131.

http://dx.doi.org/10.3390/antiox2030122
Dijkema, K.S., Beeftink, W.G., Doody, J.P., Géhu, J.M., Heydemann, B. \& Rivas-Martínez. S. 1984. La végétation halophile en Europe (Prés salés). Strasbourg: Council of Europe.

El-Morsi, M.H.M. 2010. Relative importance of salt marshes as range resources in the north western Mediterranean coast of Egypt. J. Phytol. 2: 39-50.

El-Shourbagy, M.N., Ahmed, A.M., Osman, M.E. \& Hamada, E.M. 1984. Adjustment of different halophytes to Mediterranean salt marshes of north Egypt. Phyton (Horn) 24: 101-112.

Fabregat, M., Rigual, A. \& Crespo, M.B. 2003. Saharanthus ifniensis (Caball.) M.B. Crespo \& Lledó (Plumbaginaceae), novedad para la flora europea. Acta Bot. Malac. 28: 193-195.

Greuter, W., Burdet, H.M. \& Long, G. (eds.) 1989. Med-Checklist: A critical inventory of vascular plants of the circum-Mediterranean countries, vol. 4. Geneva: Jardin et conservatoire botaniques.

Guenée, A. 1870. Notice sur l'Oecocecis guyonella Gn., et sur la galle qu'elle produit. Ann. Soc. Entomol. France, ser. 4, 10: 5-16.

Guinochet, M. \& Vilmorin, R. de 1973. Flore de France, vol. 1. Paris: Ed. du Centre National de la Recherche Scientifique.

Guyon, J.L.G. 1852. Voyage d'Alger aux Ziban, l'ancienne Zebe, en 1847. Alger: Imprimerie du gouvernement.

Iamonico, D. 2012. Amaranthus powellii S. Watson subsp. cacciatoi comb. \& stat. nov. (Amaranthaceae). Nordic J. Bot. 30: 12-16. http://dx.doi.org/10.1111/j.1756-1051.2011.01080.x

Iamonico, D. \& Peruzzi, L. 2014. Typification of Linnaean names in Malvaceae for the Italian Flora. Taxon 63: 161-166. http://dx.doi.org/10.12705/631.11

Iberite, M., Iamonico, D. \& Valletta, A. 2013. Revised typification of the name Bupleurum gracile DC. var. rollii Montel. (Apiaceae) and comparison with B. asperuloides Heldr., B. gracile D'Urv., B. marschallianum C. A. Mey and B. uechtritzianum S. Stoyanov. Pl. Biosyst. [Taylor \& Francis online] http://dx.doi.org/10.1080/11263504.2013.814601

Jarvis, C.E. 2007. Order out of chaos: Linnaean plant names and their types. London: The Linnean Society of London in association with the Natural History Museum.

Krifa, M., Alhosin, A., Muller, C.D., Gies, J.P., Chekir-Ghedira, L., Ghedira, K., Mély, Y., Bronner, C. \& Mousli, M. 2013. Limoniastrum guyonianum aqueous gall extract induces apoptosis in human cervical cancer cells involving $\mathrm{p} 16 \mathrm{INK}^{4} \mathrm{~A}$ re-expression related to UHRF1 and DNMT1 down-regulation. J. Exp. Clin. Cancer Res. 32: 30. http://dx.doi.org/10.1186/1756-9966-32-30

Laudadio, V., Dario, M., Hammadi, M. \& Tufarelli, V. 2009. Nutritional composition of three fodder species browsed by camels (Camelus dromedarius) on arid area of Tunisia. Trop. Anim. Health Prod. 41: 1219-1224. http://dx.doi.org/10.1007/s11250-008-9303-6

Linczevski, 1. 1968. Tentamentum systematıs ordinis Plumbaginalium Lindl. Novosti Sist. Vyssh. Rast. [Novitates Systematicae Plantarum Vascularium] 5: 171-177.

Linnaeus, C. 1738 ("1737"). Hortus cliffortianus. Amstelaedami [Amsterdam]. http://dx.doi.org/10.5962/bhl.title.690

Linnaeus, C. 1753. Species plantarum, vol. 2. Holmiae [Stockholm]: impensis Laurentii Salvii. http://dx.doi.org/10.5962/bhl.title.669

Lledó, M.D., Crespo, M.B., Cox, A.V., Fay, M.F. \& Chase, M.W. 2000. Polyphyly of Limoniastrum (Plumbaginaceae): Evidence from DNA sequences of plastid $r b c L$, trnL intron and $\operatorname{trn} L-F$ intergene spacer. Bot. J. Linn. Soc. 132: 175-191. http://dx.doi.org/10.1111/j.1095-8339.2000.tb01213.x

McNeill, J., Barrie, F.R., Buck, W.R., Demoulin, V., Greuter, D.L., Hawksworth, D.L., Herendeen, P.S., Knapp, S., Marhold, K., Prado, J., Proud'Homme van Reine, W.F., Smith, J.F. \& Wiersema, J.H. (eds.) 2012. International Code of Nomenclature for algae, fungi, and plants (Melbourne Code). Regnum Vegetabile 154. Königstein: Koeltz Scientific Books. http://www.iapt-taxon.org/nomen/main.php

Ozenda, P. 1983. Flore du Sahara, 2nd ed. Paris: CNRS. 
Pignatti, S. 1972. Limoniastrum Heister ex Fabr. P. 51 in: Tutin, T.G., Heywood, V.H., Burges, N.A., Moore, D.M., Valentine, D.H., Walters, S.M.M. \& Webb, D.A. (eds.), Flora europea, vol. 3. Cambridge: Cambridge University Press.

Qaiser, M. \& Siddiqi, M.A. 1984. Plumbaginaceae. Pp. 1-30 in: Jafri, S.M.H. \& El-Gadi, A. (eds.), Flora of Libya, vol. 109. Tripoli: A1 Faateh University, Faculty of Science, Department of Botany.

Quézel, P. \& Santa, S. 1963. Nouvelle flore de l'Algérie et des régions désertiques méridionales, vol. 2. Paris: CNRS.

Royen, A. van 1740. Florae Leydensis prodromus, exhibens plantas quae in horto academico Lugduno-Batavo aluntur. Lugduni Batavorum [Leiden]: apud Samuelem Luchtmans. http://dx.doi.org/10.5962/bhl.title.693

Rubio, J.C., Figueroa, M.E. \& Devesa, J.A. 1984. Ecología del género Limonium Miller en el SW de España. Anales Jard. Bot. Madrid 40: 405-413.
Trabelsi, N., Oueslati, S., Falleh, H., Waffo-Téguo, P., Papastamoulis, Y., Mérillon, J.M., Abdelly, C. \& Ksouri, R. 2012. Isolation of powerful antioxidants from the medicinal halophyte Limoniastrum guyonianum. Food Chem. 135: 1419-1424. http://dx.doi.org/10.1016/j.foodchem.2012.05.120

Turland, N.J. 2006. Lectotypification of Campanula saxatilis, Phyteuma pinnatum and Verbascum arcturus, Linnaean names of three taxa endemic to Crete. Willdenowia 36 (Special Issue): 303-309. http://dx.doi.org/10.3372/wi.36.36124

Turland, N.J. \& Jarvis, C.E. 1997. Typification of Linnaean specific and varietal names in the Leguminosae (Fabaceae). Taxon 46: 457-485. http://dx.doi.org/10.2307/1224388

Zahran, M.A.\& El-Amier, Y.A. 2013. Non-traditional fodders from the halophytic vegetation of the deltaic Mediterranean coastal desert, Egypt. J. Biol. Sci. 13: 226-233.

http://dx.doi.org/10.3923/jbs.2013.226.233 